Review

\title{
The natural rehabilitation of an anthropogenically acidified tropical Lake: Two decades of monitoring
}

\author{
Cristiano V.M. Araújo ${ }^{\mathrm{a}, \mathrm{b}, *}$, Salomão J. Cohin-de-Pinho ${ }^{\mathrm{a}}$, Carla B.A. Chastinet ${ }^{\mathrm{c}}$, Sandro L. Machado ${ }^{\mathrm{d}}$, \\ Eduardo M. da Silva ${ }^{a}$ \\ a Instituto de Biologia, Federal University of Bahia, Campus de Ondina, 40170-115 Salvador, BA, Brazil \\ ${ }^{\mathrm{b}}$ IMAR - Instituto do MAR, Department of Life Sciences, University of Coimbra, Apartado 3046, 3001-401 Coimbra, Portugal \\ ' Instituto do Meio Ambiente e Recursos Hídricos, Rua São Francisco, No. 1, 40245-060 Salvador, BA, Brazil \\ ${ }^{\mathrm{d}}$ Departamento de Ciência e Tecnologia dos Materiais, Escola Politécnica, Federal University of Bahia, 40210-630 Salvador, BA, Brazil
}

\section{H I G H L I G H T S}

- Natural rehabilitation of an acidified Lake was monitored during two decades.

- $\mathrm{pH}$, conductivity, sulphate, iron and toxicity of the water were monthly recorded.

- Toxicity levels were related to Lake pH values which ranged with rain and dry regime.

- Moving average approach using pH data showed clearly the Lake recovery process.

- Recent data highlight Lake rehabilitation and the efficiency of the containment plan.

\section{A R T I C L E I N F O}

\section{Article history:}

Received 7 November 2011

Received in revised form 21 May 2012

Accepted 23 June 2012

Available online 21 July 2012

\section{Keywords:}

Acidification

Monitoring

$\mathrm{pH}$

Rehabilitation

Toxicity

\begin{abstract}
A B S T R A C T
The rehabilitation of a pond after approximately 20 years of strong acidified conditions due to industrial and domestic waste deposition in its catchment basin is reviewed. We describe in this study the acidification process that occurred in a tropical pond in Northeast Brazil (Dunas Lake), the rehabilitation plan for the pond and the subsequent monitoring conducted over two decades. After the contamination assessment by the late $80 \mathrm{~s}$, a rehabilitation plan was carried out in the early $90 \mathrm{~s}$, in which the contaminated soil and water have been removed and reduced, respectively. No further attempt to neutralize the water or any remediation has been carried out. A toxicity monitoring plan based on toxicity assays with the fish Poecilia reticulata was employed to verify the natural rehabilitation of the pond. The data on toxicity, $\mathrm{pH}$, conductivity, sulphate and dissolved iron recorded from 1994 to 2010 were also compiled and discussed. The collected data in 2003 and 2004 indicated changes in water quality and from them complementary management actions, namely improvement in the containment plant, were conducted in 2005. Results for toxicity assays and pH results indicated interannual changes in the water quality similar to rainy-dry periods. Moving average approach using $\mathrm{pH}$ data clearly showed the recovery process of Dunas Lake as well as the importance of the containment plan to reduce the contamination. Finally, a summary of the recent situation after two decades of rehabilitation is provided.
\end{abstract}

(c) 2012 Elsevier Ltd. All rights reserved.

\section{Contents}

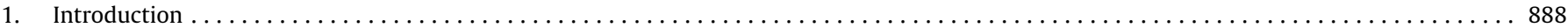

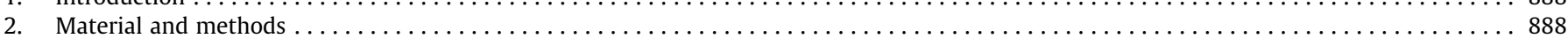

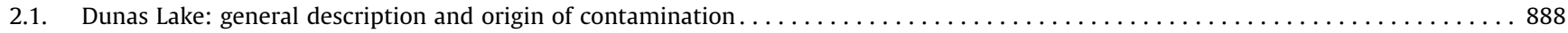

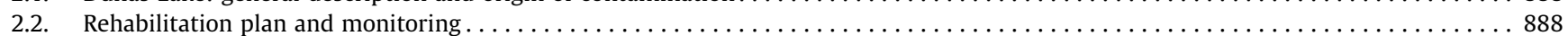

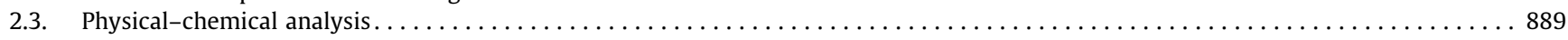

\footnotetext{
* Corresponding author at: Instituto de Biologia, Federal University of Bahia, Campus de Ondina, 40170-115 Salvador, BA, Brazil. Tel.: +55 713263 6525; fax: +55 7132636511.

E-mail address: cristiano.araujo@icman.csic.es (C.V.M. Araújo).
} 


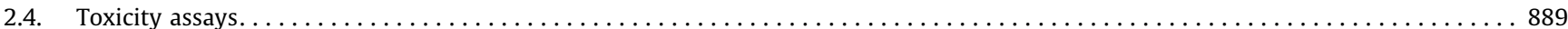

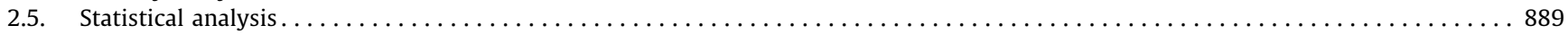

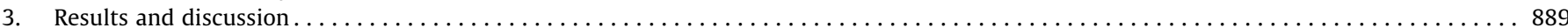

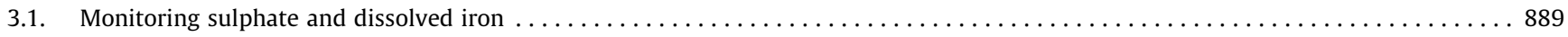

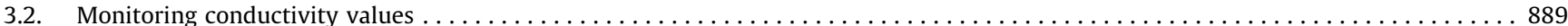

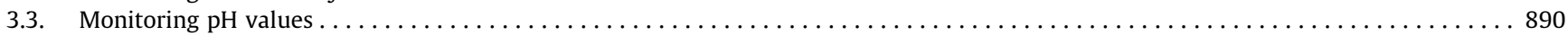

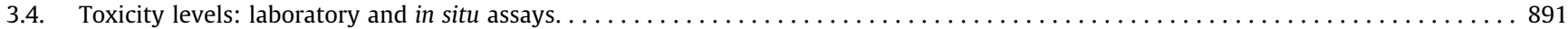

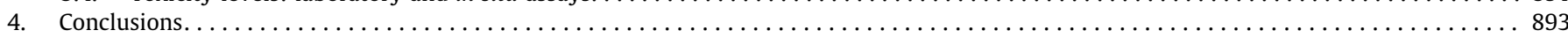

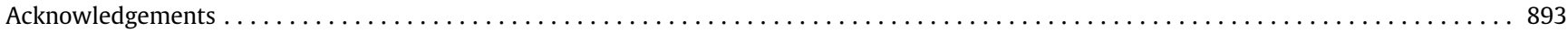

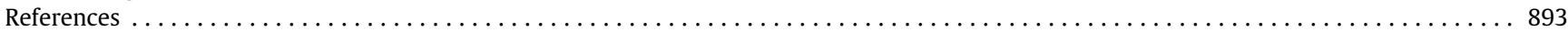

\section{Introduction}

Acidification from anthropogenic sources has attracted much attention during the past 50 years because it is one of the principal drivers of environmental disruption in many parts of the world (Gorham, 1998; Driscoll et al., 2003). Such acidification arises primarily from the consequences of acid rain and acid mine drainage, although other types of anthropogenic activities, such as vegetation burning (Geller et al., 1998; Ribeiro et al., 2002; Mello et al., 2006), and natural causes of regional importance, such as volcanic activity, may also play a role. Unfortunately, studies of acidification are primarily focused on highly developed and temperate-zone countries. In Brazil, studies of acidification are most frequently performed in the subtropical south-eastern, most industrialized region, where mining, industries, biogenic emissions and sugar-cane burning could be related to the acidification of soils and waters (Moreira-Nordemann et al., 1988; Rodhe et al., 1988; de Mello, 2001; Lara et al., 2001; Krusche et al., 2003; Martinelli et al., 2006; Mello et al., 2006).

According to da Silva et al. (2000, 1999a, 1999b), by the end of 80 's, some industrial and domestic solid residues, whose principal source was a titanium dioxide plant, were deposited on the dunes adjacent to the Dunas Lake (Camaçari, Bahia, Brazil), a pond located between coastal secondary dunes. The residues were subsequently leached by rainwater percolating through the dunes sandy soil, contaminating the ground- and the surface water. Groundand surface water $\mathrm{pH}$ decreased to values as low as 1.8 (Gomes, 1994). Chemical intervention to neutralize the deleterious effects of acidification should be the most reasonable alternative because under extremely acid conditions, the natural rehabilitation of Dunas Lake would not be considered feasible in practice. Nevertheless, these conditions could offer an excellent opportunity to monitor the capacity and time necessary for the natural rehabilitation of that ecosystem. Thus, a rehabilitation plan with no chemical intervention and, subsequently, a monitoring plan based on the measurements of a number of parameters $(\mathrm{pH}$, conductivity, sulphate and dissolved iron concentration, and toxicity assay) were designed. The basic focus of the current review is the ecotoxicological studies that were conducted over eighteen years to monitor the reduction in toxicity and the role played by $\mathrm{pH}$ in producing the toxicity. Because the $\mathrm{pH}$ was determined to be the factor primarily responsible for the toxicity (Araújo et al., 2008a), we also decided to verify the existence of seasonal fluctuations and interannual trends of the $\mathrm{pH}$ data using moving average analysis.

\section{Material and methods}

\subsection{Dunas Lake: general description and origin of contamination}

Dunas Lake is located in Camaçari (Bahia, Brazil), along the South Atlantic coast (12.803003 S, 38.219324 W). It consists of a narrow, shallow body of freshwater located in a depression sur- rounded by secondary dunes, adjacent to a wetland system that runs parallel to the coast and presents no surface connection between them. Groundwater inflow is the primary source of water input to the wetland system. A more detailed description of Dunas Lake is given in da Silva et al. (2000, 1999a, 1999b).

At the end of the 80's, large quantities of solid residues (sulphur, iron, titanium dioxide, ilmenite and domestic wastes, mostly paper, cardboard, plastic bags and wood) from the industrial activity from a titanium dioxide plant have been dumped on the dunes adjacent to the pond. The groundwater and surface waters were heavily contaminated, and the $\mathrm{pH}$ decreased to an extremely acid value (1.8). Additionally, the concentrations of dissolved iron and sulphate and the subsequent precipitation of humic acids increased. These changes affected the transparency of the water and disrupted the biological communities in the pond (da Silva et al., 2000, 1999a, 1999b). The contamination plume in the groundwater did not reach Jauá Lake, which maintained its original characteristics and has been considered to represent a reference site (da Silva et al., 2000).

\subsection{Rehabilitation plan and monitoring}

In 1992, a rehabilitation program was initiated to restore groundwater and surface water quality as well as to reduce the levels of contamination regarding to acidification (da Silva et al., 2000, 1999a, 1999b; Gomes, 1994). Initially, 34,000 Mg of residues were removed; groundwater was continuously pumped out to reduce the contamination plume, which was discharged through a marine outfall; and $16,400 \mathrm{~m}^{3}$ of industrial waste and approximately $15,500 \mathrm{~m}^{3}$ of domestic waste were hydraulically encapsulated in the dune (da Silva et al., 2000, 1999a, 1999b; Gomes, 1994). The residues confinement consisted of a cover layer with three sub-layers of soil, composed of a $20 \mathrm{~cm}$ uniform eolian sand, $40 \mathrm{~cm}$ of a poorly compacted layer of residual soil, product of the weathering of a granite/gneiss bedrock and, a $60 \mathrm{~cm}$ of compacted material similar to the previous one, from top to bottom. The water collected by the drainage system was removed through a peripheral drain installed around the system.

In 2003 data of the monitoring wells installed in the area indicated a decrease in $\mathrm{pH}$, and ecotoxicity assays using surface waters indicated a reverse trend in toxicity reduction (see subsequent subsections). These results were immediately related to failures in the containment system performance and, between 2003 and 2004, a geotechnical investigation detected failures in the cover layers, as soil permeability values in the containment layers were high and, in some points tree roots were found further bottom layer, indicating poor system performance.

Having detected that, a new cover layer was set up by October 2005 after the removal of the sand and intermediate layers, using bentonite in the bottom layer to ensure low permeability and above the new compacted layer of soil, a $2 \mathrm{~mm}$ layer of high density polyethylene (HDPE) membrane was installed to produce a 
double layer of low permeability. Finally, the sand layer was reused as part of the drainage system and for plant support. In the sand layer surface hydro-seeding technique was employed for grass support. The collected rainfall water was conducted to an infiltration pond located around $200 \mathrm{~m}$ from confinement.

\subsection{Physical-chemical analysis}

Between 1993 and 2010, surface water monthly data of $\mathrm{pH}$ and conductivity values were measured in the field, using a Digi-Sense (Cole Parmer) and Hanna HI 9033 electrodes, respectively. Sulphate (like sulphate ion: turbidimetric method) and dissolved iron (phenanthroline method) were also determined in the same samples according to APHA (1992).

\subsection{Toxicity assays}

Samples used for toxicity assays were collected in $5 \mathrm{~L}$ plastic bottles, transported to laboratory and kept at $4 \pm 1.0^{\circ} \mathrm{C}$ until the next day (less than $24 \mathrm{~h}$ ) when assays were performed. Poecilia reticulata, the guppy, was chosen due to its presence previously to the impact in the nearby wetlands and, the recommendation from OECD (1992) for use in ecotoxicity assays. The fish, native from Trinidad and Tobago, and the coastal zone of NE South America (Magurran, 2005), is a feral species, very abundant in tropical freshwaters, due to human interventions (Deacon et al., 2011). Only neonates younger than $15 \mathrm{~d}$ old, length less than $1.0 \mathrm{~cm}$, considered more sensitive (Farag et al., 1993; Petersen and Kristensen, 1998), were used in the toxicity assays. Fingerlings were obtained from a local aquarist, who bred and kept the organisms in a headwater valley stream, under natural conditions following OECD (1992) and after ABNT (2002). The organisms were transported to the laboratory in a plastic bag with sufficient air and in darkness (Baumans, 2005). In the laboratory, the fish were sorted out for size and acclimated for $24 \mathrm{~h}$ in $20 \mathrm{~L}$ glass aquaria initially containing the creek water, which was gradually replaced with dechlorinated tap water, within this period previous to experiments, under constant aeration, and used as control. Food was not provided during this period and during the experiments. The temperature $\left(26.0 \pm 1.0^{\circ} \mathrm{C}\right)$ and photoperiod $(12: 12 \mathrm{~h}$ light: dark) were maintained throughout the experiments, and static and acute toxicity with a maximum exposure time of $96 \mathrm{~h}$ (OECD, 1992; ABNT, 2002) were carried out. Briefly, the samples were placed in test vessels (1.2 L capacity), each containing ca. $900-1000 \mathrm{~mL}$ of sample. Eight to ten fish were randomly exposed in each vessel, and time was the independent variable, using five replicates per water sample. Fish mortality was checked every 10 min in the first $3 \mathrm{~h}$ of the tests, $30 \mathrm{~min}$ of the third until the 10 th $\mathrm{h}$, and at longer time intervals in the following hours. Living animals were recorded and dead fish removed (da Silva et al. 2000; Araújo et al. 2006, 2008a, 2008b).

\subsection{Statistical analysis}

For toxicity tests, the median lethal time $\left(\mathrm{LT}_{50}\right.$ : time at which $50 \%$ of the test animals were dead) was determined by Probit Analysis. Considering that $\mathrm{pH}$ seemed to be the toxicity factor most determinant (Araújo et al., 2008a), to verify the presence of seasonal fluctuations and the interannual data trend, a moving average of the $\mathrm{pH}$ values was employed, as they are to identify trends in a given measurement and to eliminate unwanted fluctuations in time series analysis (Spiegel, 1981). In this procedure, a data subset was chosen from the data set collected over a given period. This first subset was then averaged. Later, the first value used in the data subset was removed, and a subsequent data value inserted to determine the new value of the moving average. In the present study, two different criteria for calculating moving averages were employed. The first criterion produced a seasonal moving average based on 6-month subsets. The principal goal of this approach was to detect the seasonal fluctuations related to the rainy-dry periods, March to August, and September to February, respectively (da Silva et al., 2000). No reliable continuous rain data was available for the area, or even nearby sites, although a definite rain pattern is known. The second criterion used to calculate the moving average aimed to verify interannual trends in the ecosystem rehabilitation associated with the increase in $\mathrm{pH}$. This procedure was similar to the previous procedure, but the subsets included 12 months of data.

Linear correlation coefficients between sulphate and dissolved iron levels, conductivity, $\mathrm{pH}$, and toxicity were also calculated.

\section{Results and discussion}

\subsection{Monitoring sulphate and dissolved iron}

The sulphate levels are plotted in Fig. 1. The initial sulphate concentration was generally greater than $500 \mathrm{mg} \mathrm{L}^{-1}$. From 1997, the sulphate levels were lower than $400 \mathrm{mg} \mathrm{L}^{-1}$; however, those levels ranged between 60 and $170 \mathrm{mg} \mathrm{L}^{-1}$ in 1999, and decreased to 25 $( \pm 6) \mathrm{mg} \mathrm{L}^{-1}$ in 2010. Sulphate levels were significantly correlated with iron $(r=0.95 ; p<0.0001 ; n=12)$, conductivity $(r=0.98$; $p<0.0001 ; n=14)$ and $\mathrm{pH}(r=-0.76 ; p<0.05 ; n=14)$, but not with toxicity $(r=-0.32 ; p>0.05 ; n=11)$.

The levels of dissolved iron found in 1994 and 1995 ranged between 60 and $70 \mathrm{mg} \mathrm{L}^{-1}$ (Fig. 2). During the subsequent two years, this level decreased to approximately $41( \pm 13) \mathrm{mg} \mathrm{L}^{-1}$, and in 1998 , the mean value recorded was approximately $14 \pm 14 \mathrm{mg} \mathrm{L}^{-1}$ (being $27 \pm 13$ in the firsts six months and $4 \pm 0.9 \mathrm{mg} \mathrm{L}^{-1}$ in the second semester). During the last six years of monitoring (20052010), the concentrations of dissolved iron (between 0.6 and $0.1 \mathrm{mg} \mathrm{L}^{-1}$ ) in Dunas Lake water reached levels similar to those found in non contaminated Jauá Lake (unpublished data). A high content of dissolved iron prevents $\mathrm{pH}$ increases by acting as a buffer (Peine and Peiffer, 1998) and maintains high conductivity values (Klapper et al., 1998). This relation of dissolved iron with $\mathrm{pH}$ $(r=-0.73 ; p<0.005 ; n=12)$ and with conductivity $(r=0.97$; $p<0.0001 ; n=12$ ) has been recorded. Regarding the toxicity a non-significant correlation was recorded $(r=-0.34 ; p>0.05$; $n=9$ ).

The non-significant correlation data of both sulphate and dissolved iron levels with toxicity data highlight that although these parameters are important for monitoring plan, they were not able to predict potential toxicity of Dunas Lake.

\subsection{Monitoring conductivity values}

The conductivity data (Fig. 3 ) showed that the initial values observed during the first three years were always greater than $1000 \mu \mathrm{S} \mathrm{cm}^{-1}$ and attained values of approximately $2000 \mu \mathrm{S} \mathrm{cm}^{-1}$. A decreasing trend began in 1996 and was most evident during the subsequent years. The highest value, in January 1997, was approximately $1300 \mu \mathrm{S} \mathrm{cm}^{-1}$ with mean of $986 \pm 176 \mu \mathrm{S} \mathrm{cm}^{-1}$. In 1998 , during the last six months the conductivity mean was of $678 \pm$ $25 \mu \mathrm{S} \mathrm{cm}^{-1}$. During almost all of 1999 , the conductivity values were approximately $530 \mu \mathrm{S} \mathrm{cm}^{-1}$. The conductivity values exhibited a typical pattern of variability, with a pronounced seasonal component between May and August, especially during 1994 and 1999. A significant and constant reduction was evident until 2001. Thereafter, a slight increase was recorded for the next five years. However, the conductivity values decreased beginning in 2007. These data were attributed to the second plan for the con- 

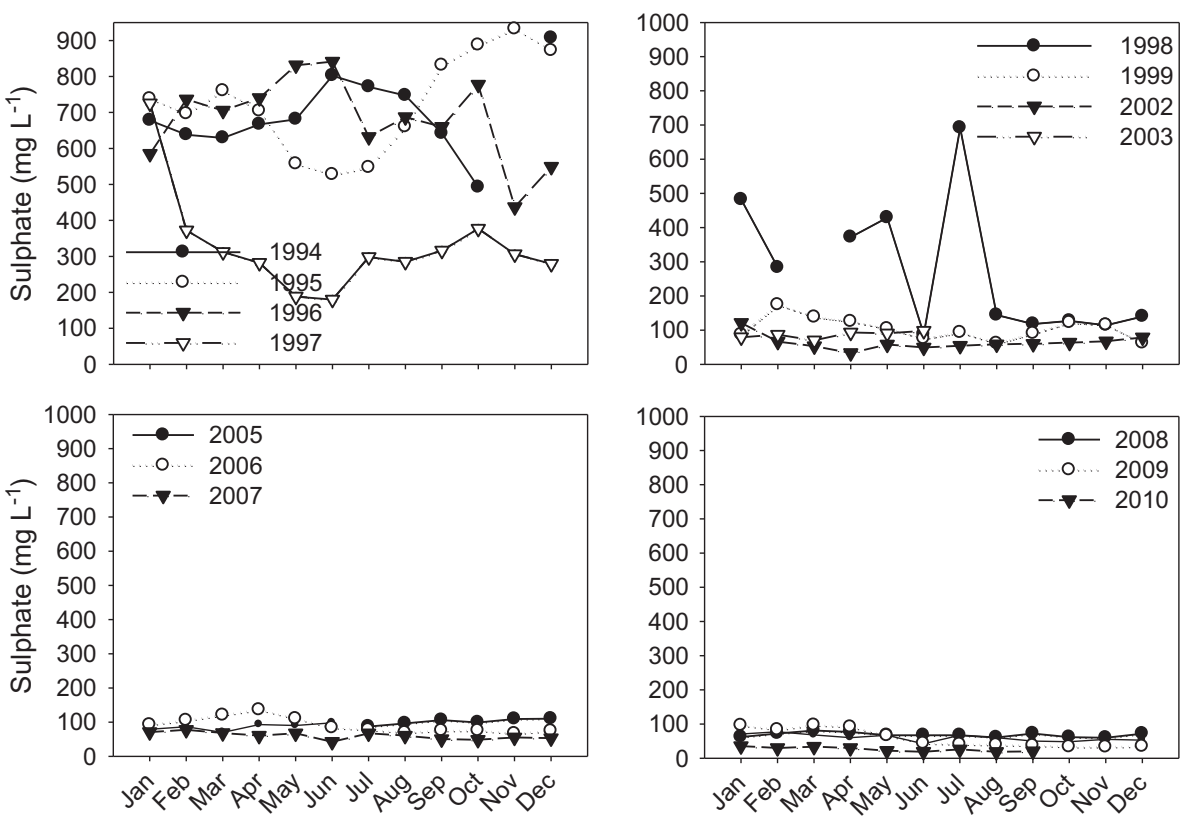

Fig. 1. Monthly sulphate values recorded in Dunas Lake water samples from 1994 to 2010.
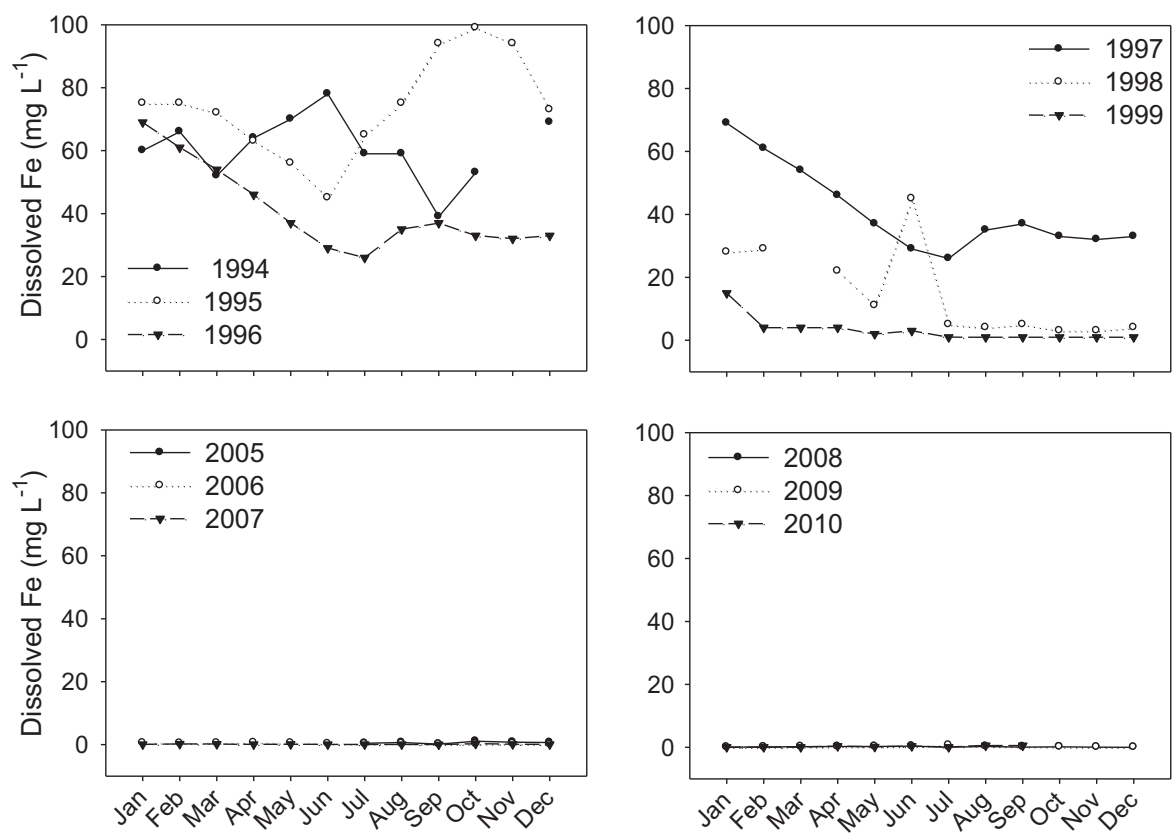

Fig. 2. Monthly dissolved iron values recorded in Dunas Lake water samples from 1994 to 2010.

tainment of the contamination. The lowest values observed $\left(174 \pm 26 \mu \mathrm{S} \mathrm{cm}^{-1}\right)$ in 2010 are very similar to those recorded in Jauá Lake $\left(109 \pm 10 \mu \mathrm{S} \mathrm{cm}^{-1}\right)$, which is considered a reference ecosystem. Conductivity values were significantly correlated with $\mathrm{pH}$ $(r=0.91 ; p<0.001 ; n=17)$; however, no correlation with toxicity was observed $(r=-0.34 ; p>0.05 ; n=12)$.

\subsection{Monitoring $\mathrm{pH}$ values}

Early pH data from Dunas Lake showed values of approximately $2.52( \pm 0.08)$ in 1994 , prior to the rehabilitation procedure (Fig. 4). During the first four years of monitoring, the $\mathrm{pH}$ values were always below 3.0 (from 2.52 to 2.68). From 1998 to 2002, the mean
$\mathrm{pH}$ values ranged between 3.0 and 3.6, but in the three subsequent years, value levelled out around a mean of $3.30( \pm 0.21)$ and 3.13 $( \pm 0.24)$ in 2003 and 2004 , respectively, not following the regular upward trend. These results provided the scenario for a new containment that was carried out by late 2005 and $\mathrm{pH}$ values have increased considerably since then. In 2010, the mean pH values reached $5.0 \pm 0.7$, which can be taken as a reference value for the region (da Silva et al., 1999a).

The $\mathrm{pH}$ data exhibited not only oscillations throughout the monitoring period but also a clear tendency to increase interannually (Fig. 5), at least for the first nine years, and after the new containment (from 2004). The seasonal moving average in Fig. 5 showed marked fluctuations, with a peak (the highest $\mathrm{pH}$ values) 

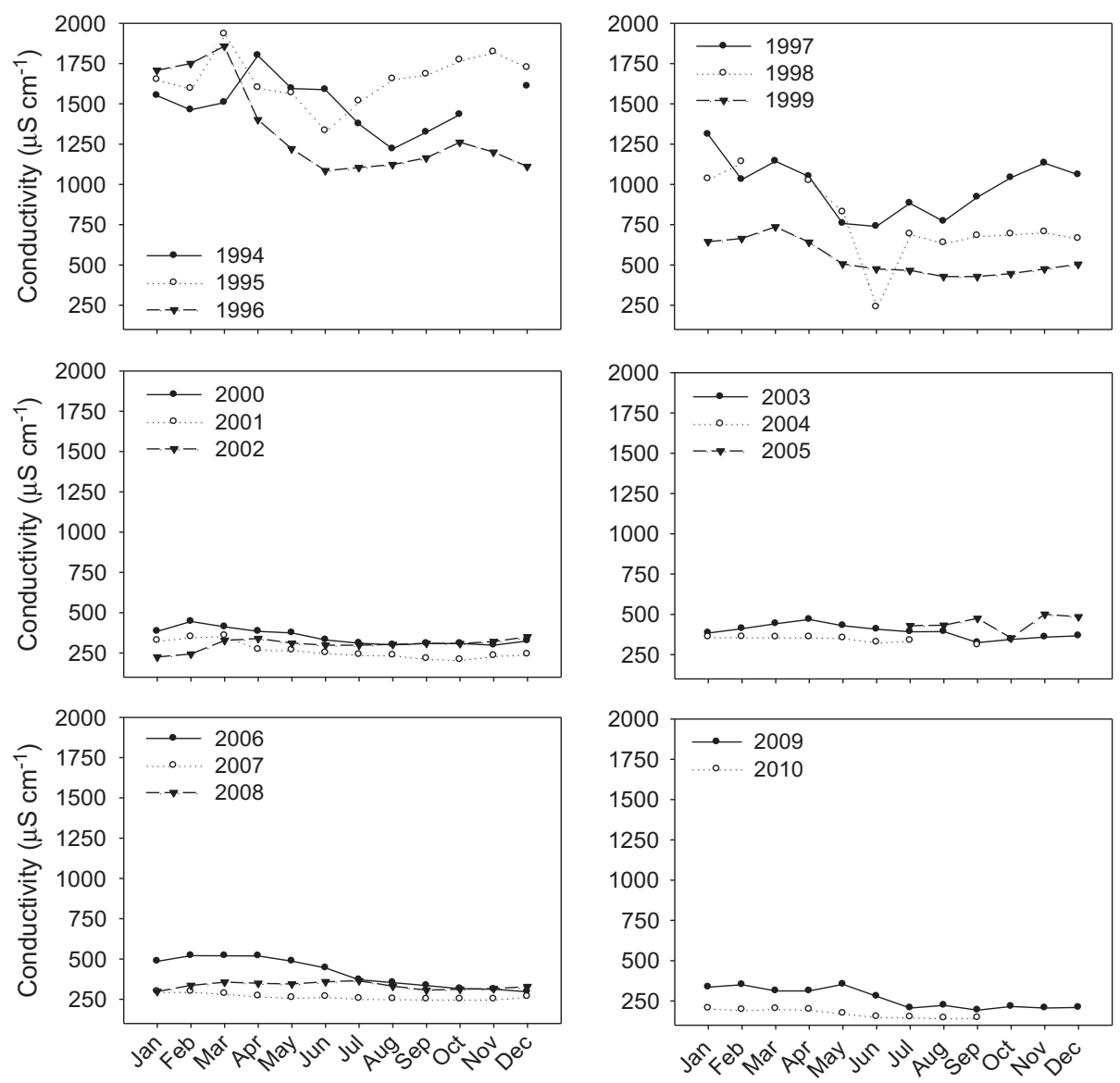

Fig. 3. Monthly conductivity values recorded in Dunas Lake water samples from 1994 to 2010.

occurring generally during mid-year (the rainy period) and a trough (the lowest $\mathrm{pH}$ values) during the last and first months of the year (the dry period). Such seasonal trend showed that rainfall affects chemical composition of the pond as indicated by da Silva et al. (1999a) for Dunas Lake. The analysis with moving averages revealed two components that were strongly related to the $\mathrm{pH}$ values. The seasonal component was influenced by rainfall and was responsible for the fluctuations around the trend of the interannual component that highlights the process of natural rehabilitation. The interannual component appears to be relatively more important owing to the increasing $\mathrm{pH}$ values than seasonal component. However, the importance of this component is reduced by the seasonal variability. To eliminate the variability related to the mean $\mathrm{pH}$ value, the moving average for 6 months, containing both the seasonal and interannual components, was decomposed by subtracting the mean $\mathrm{pH}$ calculated from the entire set of raw data (from 1994 to 2010) from each value of the moving average. Subsequently, to obtain the primary components, a data decomposition was applied to the monthly pH data set. First, the 6-month component was calculated by extracting the moving average from each $\mathrm{pH}$ value. This component eliminates the variability related to the variability of the moving average. Then, the 12-month component was calculated by extracting the 12 -month moving average from the previously calculated component to eliminate the seasonal variability. Finally, the components for 6 and 12 months were individually summed as absolute values, and the percentage of the total sum (also in absolute value) represented by each component was calculated. The importance level thus found for the interannual component was $76 \%$, whereas the importance level for the seasonal component was $24 \%$. This result highlights the greater magnitude of the annual trend of increase in $\mathrm{pH}$ than the seasonal variation.

\subsection{Toxicity levels: laboratory and in situ assays}

The ecotoxicity results for 1993 to 2010 are shown in Fig. 6 . Generally, the values recorded until 2009 are ecologically similar because the fish were unable to survive during 96-h exposure. In $2010,100 \%$ of the organisms survived over $96 \mathrm{~h}$ (reported as $96 \mathrm{~h}$ in Fig. 6). This value indicated the occurrence of a substantial change in the water quality of Dunas Lake. Since September 2010, fish (Family Erythrinidae) were observed in Dunas Lake, indicating that the environmental quality of that pond, with $\mathrm{pH}$ values around 5, is sufficient to allow colonization by fish (Driscoll et al., 2003). Algae, invertebrates and/or fish were not observed in Dunas Lake from 1992 to 2000 (Reis, 2004).

Fish populations exposed to low $\mathrm{pH}$ experience biochemical and physiological disturbances (Moiseenko and Sharova, 2006). Therefore, acidified aquatic ecosystems tend to be fish-free environments (Van Sickle et al., 1996; Nixdorf et al., 1998). Based on this premise, Araújo et al. (2008a) investigated whether the toxicity found in Dunas Lake water is related directly to the effects of low $\mathrm{pH}$ effects or is due to a higher bioavailability of toxic metals. In that study, the authors tested different $\mathrm{pH}$ values to detect possible reductions in fish survival due to increased $\mathrm{pH}$. Monthly water samples collected from Dunas Lake from March 2003 to November 2004 were treated with $1 \mathrm{M} \mathrm{NaOH}$ to obtain different $\mathrm{pH}$ values: from the original Dunas Lake $\mathrm{pH}(\mathrm{pH}$ approximately 3.0) to 6.5. The purpose of these treatments was to assess the changes in the toxicity levels after increasing the $\mathrm{pH}$. To assess only 

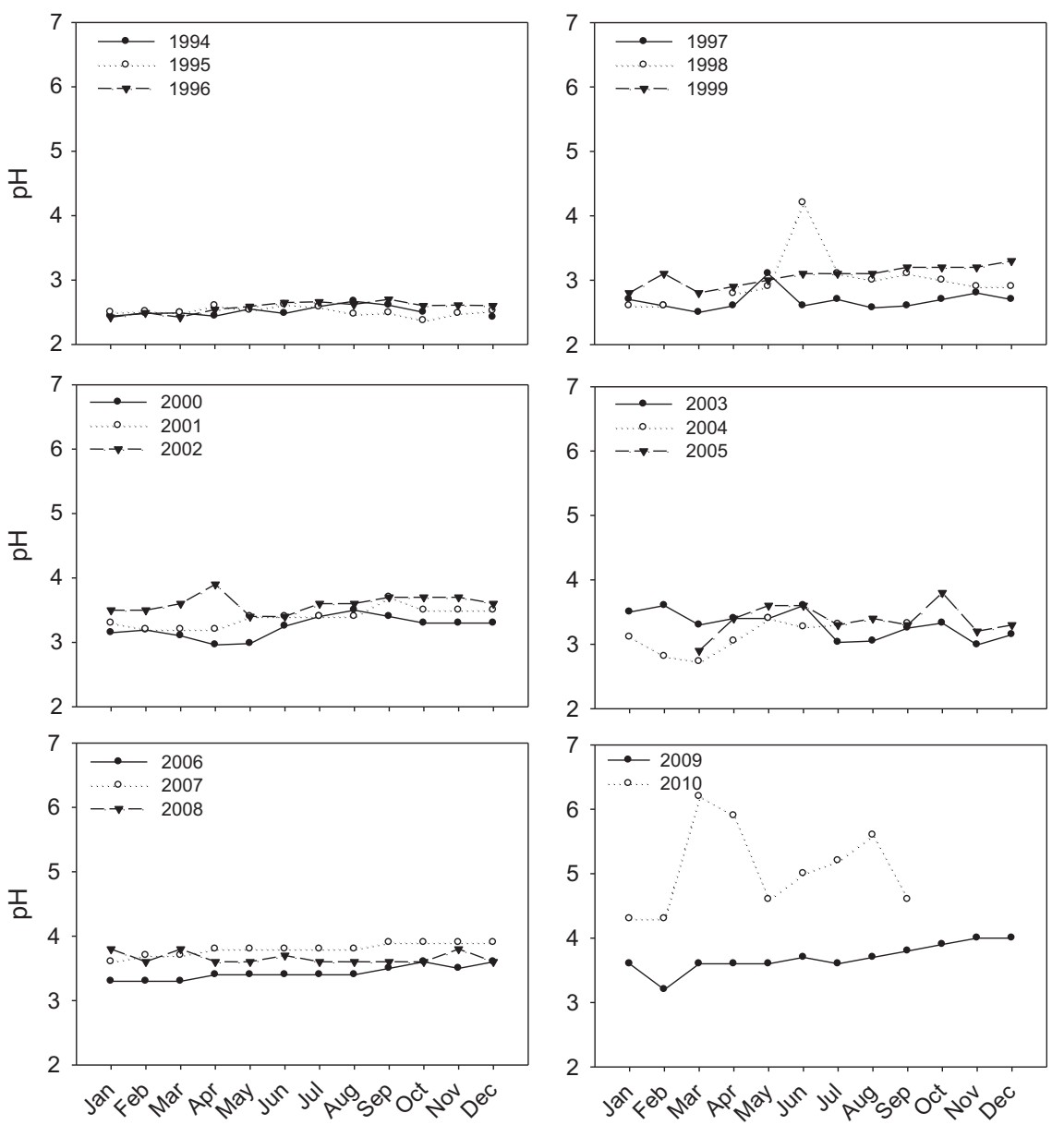

Fig. 4. Monthly pH values recorded in Dunas Lake water samples from 1994 to 2010.

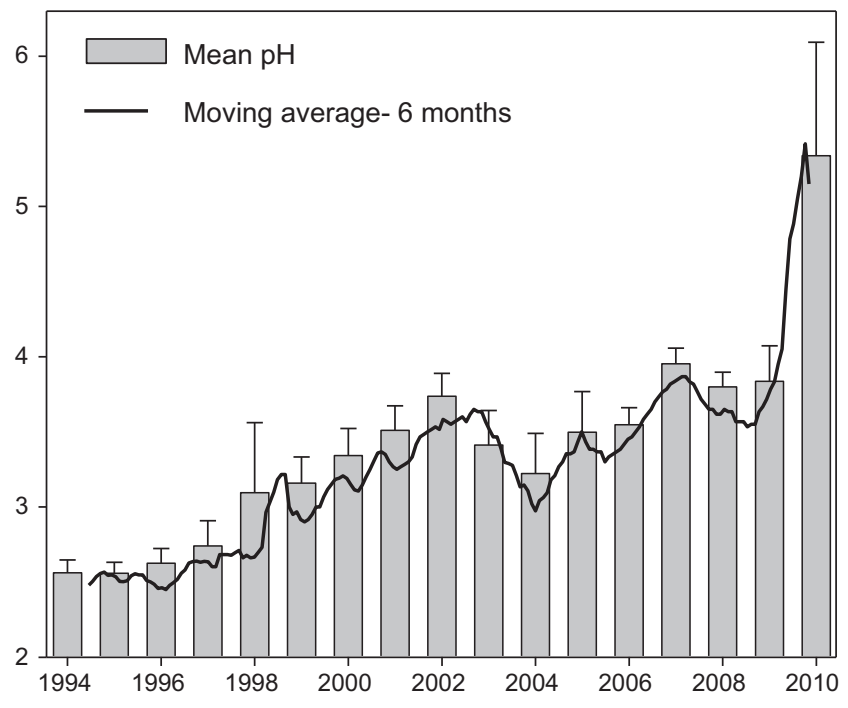

Fig. 5. Yearly mean of $\mathrm{pH}$ and moving averages using $\mathrm{pH}$ data subsets of 6 months of Dunas Lake water recorded from 1994 to 2010.

the toxic effect of $\mathrm{pH}$, the $\mathrm{pH}$ of the control water (dechlorinated tap water) was decreased with $1 \mathrm{M} \mathrm{H}_{2} \mathrm{SO}_{4}$ to the same $\mathrm{pH}$ value recorded in Dunas Lake. The results obtained from a predictive model indicated that $80 \%$ of the toxicity observed in the Dunas Lake water is due to $\mathrm{pH}(p<0.0001)$ (Araújo et al., 2008a). This model indi-

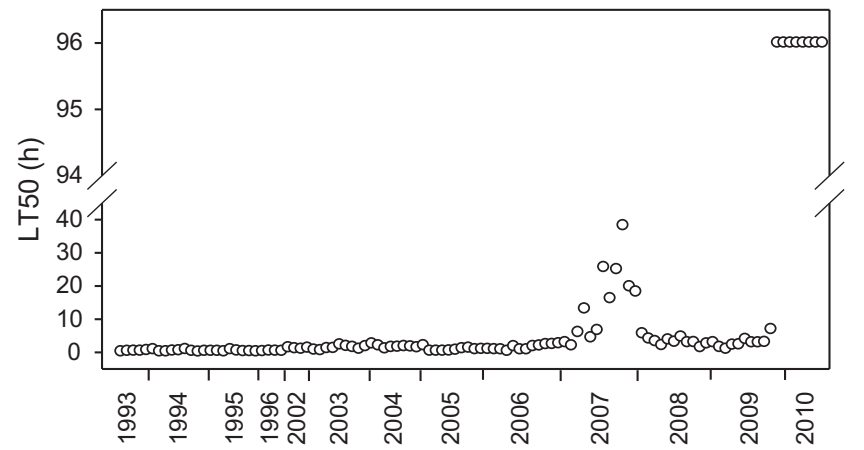

Fig. 6. Values of $\mathrm{LT}_{50}$ obtained for Poecilia reticulata exposed in the laboratory to Dunas Lake water during 1993 and 2010.

cated that the change in $\mathrm{pH}$ values simulated in the laboratory was able to predict the actual situation in the field $(p<0.0001)$. Based on the results of that study, a pH of 5 should represent the threshold that would allow the presence of fish in the lake.

Although laboratory assays are widely employed in ecotoxicological studies, they have an inconvenient feature: their results cannot be extrapolated successfully to natural ecosystems. Therefore, an in situ ecotoxicity assay was adopted beginning in July 2003 to compare the results from the field with those obtained in the laboratory. Certain discrepancies between the results of the two types of assays have been attributed to the lack of the ability to create a laboratory environment with conditions similar to 


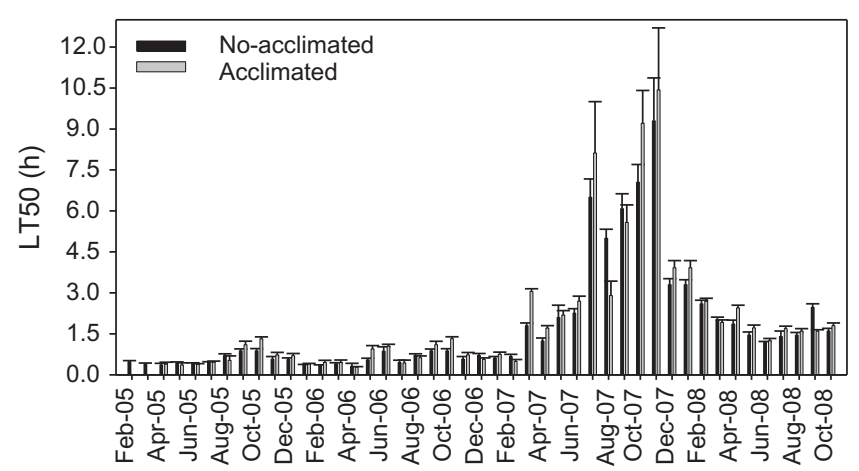

Fig. 7. Values of $\mathrm{LT}_{50}$ obtained for acclimated and no-acclimated Poecilia reticulata exposed to Dunas Lake water during 2005 to 2008 in in situ assays.

those found in the field, as well as transportation and the handling of the test organisms in the field (Pereira et al., 2000). Given these considerations, a new procedure was adopted for the in situ assays beginning in 2005. Starting in that year, the organisms were transported to the field and were maintained there for $24 \mathrm{~h}$ before the assays (in glass aquarium but with no contact with lake water). Because the length of the acclimation period had no effect on the results of the assays, after 2005 this field acclimation period was increased to $48 \mathrm{~h}$ to reduce the stress on the organisms due to transportation and handling. The results of the toxicity assay were not affected by the presence $(4.2 \pm 3.3 \mathrm{~h})$ or absence $(3.8 \pm 2.8 \mathrm{~h})$ of acclimation (Fig. 7). The lack of any effect of the transportation and handling of the organism in the field indicates that the difference between the results of the in situ and laboratory assays may be attributed to the more realistic conditions in the field, where deleterious toxic effects act simultaneously with environmental factors. The variation around standard conditions observed throughout the year is directly related to the rainfall regime through the dilution of the Dunas Lake water, as previously discussed for $\mathrm{pH}$. Beginning in June 2007, the $\mathrm{LT}_{50}$ values increased and ranged between approximately $3 \mathrm{~h}$ and $9 \mathrm{~h}$. From December 2007, the $\mathrm{LT}_{50}$ values then decreased but a clear trend to increase regarding previous years was recorded.

The use of in situ assays in the Dunas Lake biomonitoring program proved to be an effective illustration of the care required for interpreting laboratory results. Laboratory conditions may mask interactions between toxicity and environmental factors and thereby underestimate the actual toxicity. These assays also showed that if the transportation of the organisms to the field and the subsequent handling of the organisms are performed appropriately, then the uncertainties in the results resulting from possible stress to the organisms can be reduced to a considerable extent.

\section{Conclusions}

The ecotoxicological impact of a toxicant is related to the magnitude of the toxicity effect and to the intrinsic ability of the affected populations to recover. The duration of the recovery of a population also determines the extent to which a toxicant indirectly affects the community (Liess and Folt, 2010). The probability that the biota will recover from a disruption is substantially decreased if the damage has been severe and chronic (Yan et al., 2004). At the beginning of the biomonitoring program in Dunas Lake, it was not clear that doing nothing was better than doing anything. Because the input of contaminants had stopped and Dunas Lake represented a small aquatic ecosystem within a large wetland system, allowing natural rehabilitation to occur would offer an excellent opportunity to study and clarify a great number of questions about the rehabilitation of a tropical aquatic ecosystem after acidification. The results obtained from nearly two decades of monitoring reinforce the importance of the implementation of ecotoxicity assays in programs for monitoring environmental quality. Although the data obtained in the laboratory involved certain restrictions, these results proved suitable for distinguishing the effects of decreases in $\mathrm{pH}$ and for predicting the reduction in toxicity resulting from increases in $\mathrm{pH}$. In addition, new assay methods, such as in situ assessments (Araújo et al., 2006) and the use of new types of organisms, e.g., the tropical cladocerans Latonopsis australis and Macrothrix elegans (Araújo et al., 2008b), could be tested.

The increasing $\mathrm{pH}$ in Dunas Lake favoured the development of new ecological interactions. This statement is corroborated by the recent occurrence of fish that indicated a more complex food web (data not published). The first evidence of these progressive changes was furnished by Reis (2004). The study discussed the recolonisation of Dunas Lake by the flora and fauna, and the ecological interactions occurring in the lake. More recently, Saro et al. (2011) simulated recolonisation scenarios involving cladocerans (Ceriodaphania cornuta, C. silvestrii, L. australis, and M. elegans). In general, the results of this last study regarding a toxicity threshold for recolonisation by cladocerans are similar to the results given by Araújo et al. (2008a), who predicted a pH threshold greater than 5 for fish. All of these data clearly demonstrate the process of rehabilitation that is evident in Dunas Lake. Subsequent studies in this ecosystem should be focused on sediment quality, as initially performed by da Silva et al. (2000), and on recolonisation, community structure and ecological interactions as described by Reis (2004) to provide a more complete understanding of the rehabilitation of Dunas Lake.

\section{Acknowledgements}

We thank M. Morales-Pineda (University of Cádiz, Spain) for her valuable contributions and comments on the data analysis and, Cristal Global (Millennium Inorganic Chemicals) for support during the years of monitoring. E.M. da Silva and C.V.M. Araújo acknowledge receiving scholarships from the Brazilian Research Council (CNPq), and FCT (Fundação para a Ciência e a Tecnologia, Portugal - SFRH/BPD/74044/2010) for a postdoctoral grant, respectively.

\section{References}

ABNT - Associação Brasileira de Normas Técnicas, 2002. Água - Ensaio de Toxicidade Aguda Com Peixes - Parte I - Sistema estático (NBR 12714). ABNT, Rio de Janeiro.

APHA - American Public Health Association, 1992. Standard Methods for the Examination of Water and Wastewater. 18th ed., APHA, AWWA and WEF, Washington, DC.

Araújo, C.V.M., Cohin-de-Pinho, S.J., Santo, J.S., Delgado, F., Santana, L.C.S., Chastinet, C.B.A., da Silva, E.M., 2006. In situ and laboratory bioassays using Poecilia reticulata Peters, 1859 in the biomonitoring of an acidic lake at Camaçari, BA, Brazil. Chemosphere 65, 599-603.

Araújo, C.V.M., Cohin-de-Pinho, S.J., Chastinet, C.B.A., Santos, J.S., da Silva, E.M., 2008a. Discriminating the $\mathrm{pH}$ toxicity to Poecilia reticulata Peters, 1859 in the Dunas Lake (Camaçari, BA, Brazil). Chemosphere 73, 365-370.

Araújo, C.V.M. Cohin-de-Pinho, S.J., Chastinet, C.B.A., Delgado Santana, F, da Silva, E.M., 2008b. Potential of the tropical cladocerans Latonopsis australis Sars, 1888 and Macrothrix elegans Sars, 1901 as biomonitors of an acidic lake. Acta Limnol. Bras. 20, 111-118.

Baumans, V., 2005. Science-based assessment of animal welfare: laboratory animals. Rev. Sci. Tech. Off. Int. Epiz. 24, 503-514.

da Silva, E.M., Navarro, M.F.T., Barros, A.F., Mota, M.F.V., Chastinet, C.B.A., 1999a. The utilisation of Poecilia reticulata as a biomonitor in the environmental recovery of an aquatic ecosystem. Ecotoxicol. Environ. Restor. 2, 51-55.

da Silva, E.M., Barros, A.F., Navarro, M.F.T., Mota, M.F.V., Cotsifis, P., Chastinet, C.B.A., 1999b. Rehabilitation following industrial contamination: Jauá Lake, a coastal wetland in Camaçari, Bahia, Brazil. In: Streever, W. (Ed.), An International Perspective on Wetland Rehabilitation. Kluver Academic Press, Netherlands, pp. 197-203. 
da Silva, E.M., Navarro, M.F.T., Barros, A.F., Mota, M.F.V., Chastinet, C.B.A., 2000. Metals in the sediments of Jauá Lake (Camaçari, Bahia, Brazil) following an episode of industrial contamination. Aquatic Ecosyst. Health Manage. 3, 509514.

Deacon, A.E., Ramnarine, I.W., Magurran, A.E., 2011. How reproductive ecology contributes to the spread of a globally invasive fish. PLoS ONE 6 (9), e24416.

de Mello, W.Z., 2001. Precipitation chemistry in the coast of the Metropolitan Region of Rio de Janeiro. Brazil. Environ. Pollut. 114, 235-242.

Driscoll, C.T., Driscoll, K.M., Mitchell, M.J., Raynal, D.J., 2003. Effects of acidic deposition on forest and aquatic ecosystems in New York state. Environ. Pollut. 123, 327-336.

Farag, A.M., Woodward, D.F., Little, E.E., 1993. The effects of low pH and elevated aluminum on yellowstone cutthroat trout (Oncorhynchus clarki bouvieri). Environ. Toxicol. Chem. 12, 719-731.

Geller, W., Klapper, H., Schultze, M., 1998. Natural and anthropogenic sulphuric acidification of lakes. In: Geller, W., Klapper, H., Salomons, W. (Eds.), Acidic Mine Lakes: Acid Mine Drainage, Limnology and Reclamation. Springer, Berlin, pp. 3-14.

Gomes, D.C., 1994. Poluição de aqüífero costeiro de Arembepe-BA por ácido sulfúrico e compostos inorgânicos oriundos da produção de dióxido de titânio. MSc. Dissertation, Universidade de São Paulo, p. 116.

Gorham, E., 1998. Acid deposition and its ecological effects: a brief history of research. Environ. Sci. Policy 1, 153-166.

Klapper, H., Friese, K., Scharf, B., Schimmele, M., Schultze, M., 1998. Ways of controlling acid by ecotechnology. In: Geller, W., Klapper, H., Salomons, W. (Eds.), Acidic Mine Lakes: Acid Mine Drainage, Limnology and Reclamation. Springer, Berlin, pp. 401-416.

Krusche, A.V., Camargo, P.B., Cerri, C.E., Ballester, M.V., Lara, L.B.L.S., Victoria, R.L., Martinelli, L.A., 2003. Acid rain and nitrogen deposition in a sub-tropical watershed (Piracicaba): ecosystem consequences. Environ. Pollut. 121, 389399.

Lara, L.B.L.S., Artaxo, P., Martinelli, L.A., Victoria, R.L., Camargo, P.B., Krusche, A., Ayers, G.P., Ferraz, E.S.B., Ballester, M.V., 2001. Chemical composition of rainwater and anthropogenic influences in the Piracicaba River Basin, Southeast Brazil. Atmos. Environ. 35, 4937-4945.

Liess, M., Folt, K., 2010. Intraspecific competition delays recovery of population structure. Aquat. Toxicol. 97, 15-22.

Magurran, A.E., 2005. Evolutionary Ecology: The Trinidadian guppy. Oxford University Press, Oxford.

Martinelli, L.A., Howarth, R.W., Cuevas, E., Filoso, S., Austin, A., Lara, L.B.S.L., Medina, E., 2006. Sources of reactive nitrogen affecting ecosystems in Latin America and the Caribbean: current trends and future perspectives. Biogeochemistry 79, 324.

Mello, J.W.V., Dias, L.E., Daniel, A.M., Abrahão, W.A.P., Dechamps, E., Schaefer, C.E.G.R., 2006. Preliminary evaluation of acid mine drainage in Minas Gerais state, Brazil. R. Bras. Ci. Solo 30, 365-375.
Moiseenko, T.I., Sharova, O.N., 2006. Physiological mechanisms of degradation of fish populations in acidified water bodies. Russ. J. Ecol. 37, 257-263.

Moreira-Nordemann, L.M., Forti, M.C., Di Lascio, V.L., do Espírito Santo, C.M., Danelon, O.M., 1988. Acidification in Southeastern Brazil. In: Rodhe, H., Herrera R. (Eds.), Acidification in Tropical Countries. John Wiley \& Sons, Chichester, pp. 257-296.

Nixdorf, B., Wollmann, K., Deneke, R., 1998. Ecological potentials for planktonic development and food web interactions in extremely acidic mining lakes in Lusatia. In: Geller, W., Klapper, H., Salomons, W. (Eds.), Acidic Mine Lakes: Acid Mine Drainage, Limnology and Reclamation. Springer, Berlin, pp. 147166.

OECD - Organisation Economic Co-operation and Development, 1992. Guideline for testing of chemicals. Fish Acute Toxicity Test. OECD Guideline for Testing of Chemicals, Paris.

Peine, A., Peiffer, S., 1998. In-lake neutralization of acid mine lakes. In: Geller, W. Klapper, H., Salomons, W. (Eds.), Acidic Mine Lakes: Acid Mine Drainage, Limnology and Reclamation. Springer, Berlin, pp. 47-63.

Pereira, A.M.M., Soares, A.M.V.M., Gonçalves, F., Ribeiro, R., 2000. Water-column, sediment, and in situ chronic bioassays with cladocerans. Ecotoxicol. Environ. Saf. 47, 27-38.

Petersen, G., Kristensen, P., 1998. Bioaccumulation of lipophilic substances in fish early life stage. Environ. Toxicol. Chem. 17, 1385-1395.

Reis, I.S., 2004. Monitoramento da evolução das comunidades biológicas da Lagoa das Dunas após episódios de contaminação ácida, Camaçari - Bahia - Brasil. MSc. Dissertation, Universidade Federal da Bahia, p. 73.

Ribeiro, R., Lopes, I., Pereira, A.M.M., Gonçalves, F., Soares, A.M.V.M., 2002. Surviva time of Ceriodaphia dubia in acid waters with metal contamination. Bull. Environ. Contam. Toxicol. 64, 130-136.

Rodhe, H., Cowling, E., Galbally, I., Galloway, J., Herrera, R., 1988. Acidification and regional air pollution in the tropics. In: Rodhe, H., Herrera, R. (Eds.) Acidification in Tropical Countries. SCOPE 36. John Wiley and Sons, Chichester, pp. 3-39.

Saro, L., Lopes, I., Chastinet, C.B.A., Cohin-de-Pinho, S.J., Moreira-Santos, M., da Silva, E.M., Ribeiro, R., 2011. Potential re-colonisation by cladocerans of an acidic tropical pond. Chemosphere 82, 1072-1079.

Spiegel, M.R., 1981. Theory and problem of statistics. MsGraw-Hill International, Singapore. p. 359.

Van Sickle, J., Baker, J.P., Simonin, H.A., Baldigo, B.P., Kretser, W.A., Sharpe, W.E. 1996. Episodic acidification of small streams in the northeastern United States: fish mortality in field bioassays. Ecol. Appl. 6, 408-421.

Yan, N.D., Girard, R., Heneberry, J.H., Keller, W.B., Gunn, J.M., Dillon, P.J., 2004 Recovery of copepod, but not cladoceran, zooplankton from severe and chronic effects of multiple stressors. Ecol. Lett. 7, 452-460. 